Published in: Art History, Vol. 26 No. 3 (2003) pp. 220-243

\title{
Max Dvořák: Art History and the Crisis of Modernity
}

\section{Introduction}

In this article I intend to examine the work of the Czech art historian Max Dvořák (1874-1921). Widely known and read during his lifetime and immediately afterwards, he has, in the anglophone world, sunk into semi-oblivion. Aside from its impact on students and followers such as Otto Benesch, Dagobert Frey or Robert Hedicke, his notion of art history as the history of ideas or spirit (Geist) has been of limited significance for subsequent scholarship. ${ }^{1}$ This stands in contrast to the situation of his colleague Alois Riegl, or contemporaries such as Aby Warburg and Heinrich Wölfflin, who have enjoyed a constant renewal of critical attention. Dvořák has largely been relegated to the periphery in histories of art historical writing, and the translation 'industry' of the past 20 years, which has made many key German-language texts accessible to an anglophone readership for the first time, has largely passed him by. ${ }^{2}$ Such neglect partly reflects the fact that while Riegl and others have provided a catalyst for methodological reflection within art history, the work of Dvořák has failed to stimulate a similar level of debate. Partly, however, it also stems from the fact that he is viewed as having contributed to a genre of art historical writing that 'verged on the popular, the sensational and the grandiose,' which in its more extreme forms led to an antisemitic and nationalistic suspicion of abstraction and theory. ${ }^{3}$ I would like to suggest, however, that such a dismissive summary constitutes a narrow view. In many respects his writing acts as a barometer of many of the tensions of the early twentieth century intellectual life, and it is precisely because of the awkward political and cultural questions it raises that it merits renewed study. My concern with Dvořák is thus motivated less by a desire for a simple recovery or restitution than by a conviction that his writing casts important light on the socio-cultural situation that produced art historical discourses in the early decades of the twentieth century.

At the root of my argument are two basic contentions: first, that the work of Dvořák in particular, and of the Vienna School of art history more generally, has to be viewed against the crisis of Viennese modernity and, second, that Dvořák's writing represents an inflection, within art history, of a wider set of discourses of identity, modernity and culture. The first contention is not at first sight novel. A discursive formation 
Published in: Art History, Vol. 26 No. 3 (2003) pp. 220-243

that established its institutionalised forms in French, German and Austrian universities in the late $19^{\text {th }}$ century, the parallels between academic art history and modernism have long been recognised. As early as 1928 Mikhail Bakhtin had commented on the modernity of the discipline while, more recently, Elizabeth Mansfield has claimed that 'Art history was formed by the same impulse that created the advertising agency, the department store and even the labor union..${ }^{4}$ In considering Dvořák, however, I shall be arguing that the modernity of his writing can best be gauged in terms its relation to contemporary social and cultural theory, and in particular that Dvořák was attempting to produce a theory of modernity through the lens of art history. Finally, I shall examine the significance of his work for the historical analysis of the discipline of art history; as I shall suggest, Dvořák and the Vienna School raise important questions about the scope and aims of history of art history.

\section{Van Eyck to El Greco: Habsburg Allegories}

Dvořák was born the son of the archivist and librarian of the Palace of Roudnice on the Elbe in Northern Bohemia, into a family that had for two generations been closely linked to a seat of considerable cultural significance - the Ducal seat of Raudnitz. ${ }^{5}$ Initially educated in Prague, he came to Vienna in 1895, where he completed his Habilitation in 1901 on thirteenth- and fourteenth-century Bohemian manuscript illumination. ${ }^{6}$ He was appointed as a Privatdozent in the history of art (the most junior academic appointment) in 1902 and three years later, on the premature death of Alois Riegl, was appointed Associate Professor. In 1909 he became a full professor, although under the problematic circumstances of a dispute over the succession to the Chair held by Franz Wickhoff (1853-1909). The post was offered to Josef Strzygowski (1862-1941), a notorious nationalist ideologue, but in recognition of his achievements, Dvořák was appointed to a specially created second Chair.

Dvořák is most frequently known for the collection of essays, Kunstgeschichte als Geistesgeschichte (Art History as the History of Ideas) published posthumously and since translated into English. ${ }^{7}$ This constitutes only a small part of his output, however, being part of a five-volume edition of his collected writings that also included two volumes of lectures on the Italian Renaissance, an early study of Hugo and Jan van Eyck, 
Published in: Art History, Vol. 26 No. 3 (2003) pp. 220-243

and a further collection of essays. ${ }^{8}$ In addition, Dvořák made a substantial contribution to the field of conservation; after the death of Riegl he took over his position as director of the Central Commission for the Preservation of Artistic and Historical Monuments, in which capacity he continued his teacher's groundbreaking work in conservation policy and practice, including publication of the Yearbook of the Commission (Kunstgeschichtliches Jahrbuch der Zentralkommission für die Erhaltung der Kunst- und historischen Denkmale) and the establishment, in 1907, of a series of publications - Österreichische Kunsttopographie - that aimed to form an inventory of the entire corpus of extant works of art and architecture in Austria-Hungary. ${ }^{9}$ There remains, too, a substantial body of unpublished lectures and other writings in the archive of the University of Vienna.

Although he was a popular figure, Dvořák's career was not untroubled. In particular it was marked by a feud with Strzygowski (continuing an earlier feud between Strzygowski and Riegl) that reached a calamitous climax when Strzygowski formed a breakaway institution, causing a damaging fracture in the Institute of Art History that was only resolved once he retired in 1933, Dvořák having already died twelve years earlier. ${ }^{10}$ While this split is often cast in terms of methodological differences, nationalistic politics played a significant role. Although of Polish origin, Strzygowski had become committed to an essentialist ideology of ethnic identity and origins, oriented around a Nordic-Aryan axis which, in addition to prefiguring the political landscape of the 1930s, also ran counter to the cosmopolitanism of AustriaHungary, of which Dvořák and, paradoxically, Strzygowski himself, were obvious beneficiaries. Within the scholarly environs of the university the cosmopolitan Habsburg empire was already disintegrating.

The Dvořák-Strzygowski affair and its aftermath encapsulated the socio-political tensions of the declining Habsburg régime, which became evident in an increasing fragmentation of cultural and political life. Yet while it provided a particularly striking instance of the impact of such tensions on academic discourse, a sense of cultural dislocation and disunity was evident in the work of Riegl and Wickhoff a generation earlier. Wickhoff was usually associated with a philological and connoisseurial attention to primary sources and materials, but his best known work was an edition of the fifth-century illuminated Genesis manuscript in the Nationalbibliothek in Vienna, in which he rehabilitated early Christian art, outlining its distinct 
Published in: Art History, Vol. 26 No. 3 (2003) pp. 220-243

narrative principles and thereby challenging the hegemony of classical taste in contemporary scholarship. ${ }^{11}$ This critique of the canon of art history was accompanied by a scepticism towards periodisation, which he regarded as a purely heuristic procedure bearing no relation to any putative history-in-itself of art. As he argued, 'All the divisions we make signify nothing other than the fact that faced with the volume of material, we occasionally need to pause to regain our breath. ${ }^{12}$ In part Wickhoff's assertion drew on a neoKantian theory of history, emphasising the notion of history as construct, widespread since the publication of Gustav Droysen's influential text Historik in $1858 .{ }^{13}$ It was also motivated, however, by a desire to challenge the traditional taxonomies in the field of art history, in the name of historical and aesthetic relativism.

Riegl also recognised the fractured nature of the history of art, referring disparagingly to educated lay persons "who wish above all to see their need satisfied for unity in the history of art, without submitting to any doubts about the accuracy of the insights thereby obtained. ${ }^{14}$ For Riegl this essentially aesthetic, rather than scientific, need was to be resisted, and his interest in 'peripheral' or 'decadent' eras in the history of art can be linked both to scepticism regarding traditional periodisation and also to the fact that his earliest concerns were with debates in the history of the decorative arts, in which the normative values of art historical discourse were of considerably less importance. Yet while fully recognising the apparently disjointed nature of the history of art, Riegl was ultimately preoccupied with the possibility of establishing the laws of a deeper underlying continuity. His first substantial publications, Carpets of the Ancient Near East and Questions of Style were both concerned to demonstrate the debt of Islamic and Near Eastern art to classical antiquity. ${ }^{15}$ As Margaret Olin has suggested, Riegl openly identified with the ideology of the Habsburg Empire as a multi-ethnic polity, and his attempt to establish a common origin for a diverse range of artistic practices represented a translation of his wider political stance into the concerns of art history. ${ }^{16}$ Thus Riegl celebrated Baroque culture both for its role in anticipating his own times and also for its mongrel character, constituting an often contradictory combination of motifs of northern and southern cultural traditions. $^{17}$ 
Published in: Art History, Vol. 26 No. 3 (2003) pp. 220-243

By the time Dvořák was writing a decade and more later, it was no longer tenable to hold on to such Habsburg fantasies. His work became deeply immersed in the problematic nexus of national politics and art production, but Dvořák addressed the issue in a way that diverged from Riegl and indicated the changed times in which he was working. ${ }^{18}$ Although standing in opposition to the nationalism of Strzygowski or Julius Langbehn, whose Rembrandt as Educator co-opted Rembrandt as a German and set up the explosive opposition of Germanic 'Kultur' and French 'civilisation,' Dvořák nevertheless stressed the role of national identities in the formation of a plurality of art practices, and this increasingly becomes evident in the works written from 1914 onwards. ${ }^{19}$ As a Czech working in a state that was fragmenting along ethnic lines with the onset of the war, he could hardly not be aware of this issue, and he occupied a complex position. Although the member of an ethnic minority - Czech was his first language and he wrote a number of articles and reviews in Czech - Dvořák nevertheless internalised German national sentiment to the extent that much of his work was focused on emphasising and retrieving the specificities of the Germanic cultural spirit. In Idealism and Naturalism in Gothic Sculpture and Painting, for example, he argues that the incomprehension with which medieval and Gothic art was met until the early nineteenth century was largely a product of the dominance of the Italian aesthetic and historiographic theories of the Renaissance which, 'stemming from the artistic condemnation of Gothic in the Quattrocento, survived the deeply-felt historical discovery of medieval art in the last century and has simply adopted new scholarly guises. ${ }^{20}$ Retrieving the overlooked in the history of art was intimately connected with a contestation of the hegemony of certain national cultures and the assertion of others.

Dvořák's work came to be intimately involved in the politics of early twentieth-century nationalism, and through the course of his career he became increasingly preoccupied with historical caesuras and fractures. Beginning with a conception of art history as the study of the evolution of genetic series, an undoubted nineteenth-century inheritance, Dvořák tended to stress those breaks that could not be placed in a straightforward developmental series. Such breaks also came to be read by Dvořák in terms of the differences of national cultural traditions. In addition, however, his focus can also be seen as a reflection of the topos of modernity as crisis, in which the idea of regular laws and series was seen as problematic. 
Published in: Art History, Vol. 26 No. 3 (2003) pp. 220-243

History was thus viewed not as a regular process of change but rather as a succession of jolts, irruptions and displacements.

In his early work Dvořák still held to an evolutionary model of continual historical change inherited from Riegl. He concludes his Habilitation, for example, by discussing 'the great stream of artistic development, a single world-wide historical course, which, beyond any external historical disturbance, or any local or temporary influences, is determined by the inner forces and laws of a given general psychological condition and the fixed artistic problems contained therein. ${ }^{, 21}$ This view, drawing on Riegl's concern with the inner laws of art historical development, would later reappear as the basis of a critique of the mythology of original genius. In The Enigma of the Art of the van Eyck Brothers, published in 1904, Dvořák focused on the puzzle presented by the apparently enormous gulf between the work of the Netherlandish painters and that of their Gothic predecessors. ${ }^{22}$ What was commonly recognised as a central development in the history of art - the birth of oil painting in Northern Europe - had, since the publication of Karel van Mander's Schilderboek in 1604, been viewed as a mysterious irruption explained by means of clichés about the original genius of Jan and Hubert. ${ }^{23}$ Dvořák was concerned to counter such mythification, in line with his general view that 'A particular culture is not something that is simply given, like some fairytale bird flying in suddenly from afar ... It is a historical formation that can be neither discovered nor learnt in a day, nor altered through some act of human will alone, but which is determined by a long historical development $\ldots{ }^{24}$ Challenging the traditional myth, Dvořák traced the genealogy of early Netherlandish painting in order to demonstrate that the 'new' naturalism of the early fifteenth century was merely one development in a continuous sequence of changes, leading from Italian painting of the Trecento to French book illumination to the work of Jan and Hubert van Eyck. The apparent originality of the work of the van Eyck brothers stemmed from their position in a series of reinterpretations of previous artistic and cultural traditions. As Dvořák himself concludes, 'The basis of the new style both of Jan van Eyck and of the new art in general was no mystery, which either he, or one of his contemporaries, or his "era" had discovered for the first time. Its secret, the secret of the new art, consists in the development of art by new cultures in central Europe who had taken over the inheritance of classical antiquity. ${ }^{, 25}$ 
Published in: Art History, Vol. 26 No. 3 (2003) pp. 220-243

Dvořák's early work focuses on a close philological reading of individual works coupled with a painstaking gathering together of historical documents and other sources. In his later writings, however, he renounced close, stylistic analysis and connoisseurial attention to individual artworks in favour of much broader speculation about the history of collective cognitive structures and beliefs and their manifestation in art. He also turned away from his former attachment to the idea of a continuous and univocal history of art. In an article on the methodological demands of art historical research published on the eve of the war Dvořák makes a telling comment on the landscape of the discipline;

... a universal history of art is conceivable only in the format of an encyclopaedia. In place of the untenable notion of a standard either of perfection or decline, or of consistent development, we must think in terms of a multiplicity of developmental series that only form a unity in timeless infinity. Within the finite domain of history, however, these can only partly be brought together into a genetic relation. Doubtless at various times there existed points of contact and mutual influence between, for example, the art of Europe and the Far East. Yet in comparison with these moments of commonality, that which divides them, and which cannot be brought into any causal relation, is so great and unbridgeable that the history of art can only be given some kind of coherence when viewed from the perspective of one of these two artistic domains. A unified genetic development is not possible. ${ }^{26}$

And later he adds that;

Extension of art historical research into ever more areas is a matter of the greatest necessity ... for there is no art which might not in the future become an important factor, even if in the past its influence was of limited historical significance. ${ }^{27}$

In other words, it is impossible to gain a panoptic vision of the totality of the art historical field; the traditional idea of the world history of art is broken down into a plurality of incommensurable practices. In addition, even within individual cultural traditions, the canon is never fixed; while he holds onto the idea that a concern with tracing developmental sequences remains a central task for the art historian, Dvořák 
Published in: Art History, Vol. 26 No. 3 (2003) pp. 220-243

puts forward the image of history as palimpsest. And this relates directly to his own work, in that his scholarly attention to mannerism, the baroque and other anti-classical artistic practices developed in parallel with an interest in contemporary art, from Impressionism through to Expressionism. Indeed, in the place of a continuous evolution in the history of art Dvořák came to see history as shaped by a series of correspondences between the present and the past. This reflected a complex attitude towards the history of art in which historical correspondences served both the construction of an historical genealogy (and ultimately legitimisation) for modern art, and also as the basis of a critique of modernity. This is evident, for example, in his reading of Tintoretto and his relation to modern art. The putative optical, painterly qualities of the Venetian painter's work led Dvořák to posit Tintoretto as the ancestor of modernism, which he initially identified with Impressionism.

In lectures on Baroque art from 1905 / 1906, for example, Dvořák constructs a genealogy of modernism in which Tintoretto constitutes 'the point of origin of the development that led to Velázquez, Rembrandt and to the art of our times, ${ }^{28}$ a history that is then pushed further back to include Titian. In the same lectures Dvořák refers explicitly to Titian's 'impressionism,' adding that Titian's works are 'gallery pictures in our sense of the word, in which the artist could let himself be led by an artistic idea and by the problems he was concerned with. ${ }^{29}$ Thus, in addition to his role as a stylistic ancestor to modernity, Titian also prefigures the autonomy of modern art. Such a reading was heavily indebted both to the historiography of Riegl - for whom post-Renaissance art was characterised by a shift from haptic to optical perception - and to the aesthetic theories of Konrad Fiedler or Adolf von Hildebrand, who viewed the focus on opticality as essential to modernism. ${ }^{30}$ More generally, too, the idea that Mannerism and the Baroque stood at the origins of modern 'impressionistic' art had become a commonplace at the turn of the century. ${ }^{31}$ Wickhoff and Riegl had drawn the connection while, most notably, the Secessionist exhibition of 1903 on The Development of Impressionism in Painting and Sculpture included the work not only of French artists of the previous decades, but also Rubens, Velázquez, Vermeer and Tintoretto. ${ }^{32}$ As Robert Jensen has demonstrated, this was part of a project of legitimising contemporary art and hence also making it more marketable. ${ }^{33}$ Yet it was only some 40 years earlier that Jakob Burckhardt had denigrated mannerism and Baroque art as 'raw and deviant; ${ }^{34}$ to claim ancestry from a 'deviant' artistic form thus remained a 
Published in: Art History, Vol. 26 No. 3 (2003) pp. 220-243

provocative gesture linked to the contestation of a univocal presentation of the historical development of art.

Ten years after his Baroque lectures Dvořák radically reinterpreted the meaning of Tintoretto, and this was intimately bound up with his re-reading of modernity. Impressionism had given way to an emphasis on subjective inwardness; the optical correspondences between past and present were no longer the central focus, but rather an enhanced spirituality. In a lecture of 1914 on Tintoretto Dvořák argued that the Venetian painter's work 'is more than imitation, it is an intensification of the magical interplay between spectator and the object, and this is the characteristic of the ultimate style of Tintoretto: a heightening of the means of painterly expression, to a level of visionary expression, both superhuman and supernatural, together with compositions which, equally, offer a visionary representation of supernatural events. ${ }^{35} \mathrm{~A}$ similar view of Tintoretto is expressed elsewhere in another lecture on the same subject; the painter's work is marked by a dominance of 'feeling and the irrational. ${ }^{36}$ Dvořák also refines his earlier impressionistic genealogy for Tintoretto's work, for 'the entire legacy of realistic depiction, formal solutions and colorific effect that art adopted from its earlier development now receives a new meaning; it is no longer a selfsupporting content, but rather the effect of a higher spirituality and the expression of immaterial events ...' and Dvořák adds that 'In this, Tintoretto was close to Rembrandt, with whom he shared the conception and employment of dark and light ... for Titian [it was] an element of impressionistic coloration; but for Tintoretto it became a means for expressing poetic fantasy and for granting the representation greater spiritual depth - was later was the case with Rembrandt. ${ }^{37}$ Tintoretto is thus an Italian whose work has the greatest affinities with the art of the North.

This re-reading of Tintoretto represents a wider shift in Dvořák's work; the history of art is now marked by 'the eternal struggle between material and spirit. ${ }^{38}$ Hence Dvořák sets up a series of binary oppositions idealism vs. realism, Christian vs. classical, mannerist vs. Renaissance - in which the one, seen as a primarily spiritual manifestation, is valorised over the other. The connection with Impressionism is not entirely lost; he views the catacomb paintings of Rome as examples of ancient impressionism, defined as the goal of 'depicting things not as they objectively reveal themselves to experience, but as they appear to 
subjective perception when transformed into immaterial impressions. ${ }^{, 39}$ The meaning of such impressionism is changed, however, for now it signifies a withdrawal from material objectivity into the world of the inner spirit. Indeed, Dvořák argues that understanding the works of Tintoretto is dependent on learning 'to view the development of art not from the perspective of the imitation of nature and of formal problems, but with a view to the deepening of the purely spiritual ...,40

The turn to the spiritual becomes an increasingly dominant concern of Dvořák's later work. It informs, for example, his interpretation of Dürer's Four Horsemen of the Apocalypse, according to which Dürer's print demonstrates the specifically German nature of such spirituality, in contrast to the art of Italy, which offers no insight into the subjective life world of its subjects. ${ }^{41}$ In particular, Dürer's print exhibits the 'impulse to view the world as a problem of the inner life, and to see art as a means of engaging with God and the Devil, with this world and the next, with oneself and whatever motivates others in general ... ${ }^{42}$ A similar frame governs Dvořák’s reading of Michelangelo, whose work is seen as the expression of a new 'individualising idealism, ${ }^{43}$ or his interpretation of the post-classical spiritualism of early Christian catacomb painting, or, most famously, of El Greco, whose oeuvre is the viewed as the visual expression of the heightened religiosity of the Counter-Reformation. ${ }^{44}$

Dvoŕák's 'turn' to the spiritual has been compared with contemporary currents in the visual arts - in particular the theosophic abstraction of painters such as Kandinsky. ${ }^{45}$ Such a connection could be read as indicating a shift in his engagement with modernism, from Impressionism and the Viennese Secession to Expressionism. His sympathy with the latter is well-attested; one of his final outputs was an essay on Kokoschka. ${ }^{46}$ Dvořák himself freely admitted the intimate connection between art practice and art historical judgement; in the lectures of 1915/16 that formed the basis of his book on Gothic painting and sculpture, he suggests that the dominance of classical antiquity within art historical discourse of the nineteenth century was a clear reflection of the hegemony of naturalistic values within contemporaneous art practice. ${ }^{47} \mathrm{He}$ was also clear about the consequences of such a view for an understanding of the present; 'New times bring new themes and the great change that has occurred in our relation to art and consequently in the entire way 
Published in: Art History, Vol. 26 No. 3 (2003) pp. 220-243

we view art, compels adoption of an alternative perspective to that customarily applied hitherto in approaching the subject matter of the past. ${ }^{48}$

A notable aspect of Dvořák's writing is the attempt to explain the reception history of the various phenomena he examines. I have already mentioned his explanation for the belated acknowledgement of Gothic art. At the conclusion of his essay on El Greco and Mannerism he goes further, offering an account not only of changing aesthetic norms but of more general cultural shifts, in particular the rise of scientific modernity, that led to the eclipse of the Cretan painter's oeuvre; 'Few words are needed to describe how, inevitably, El Greco fell ever more into oblivion during the following two centuries dominated by the natural sciences, mathematical thinking, belief in causality, technical progress and the mechanisation of culture, forming a culture of the eye and the brain, but definitely not one of the heart. ${ }^{49} \mathrm{He}$ also scrutinises the meaning of Italian Renaissance in the subsequent history of European culture. In his early study of the van Eyck brothers he declares: 'There are anomalies in historiography which are hard to understand. Amongst these are the cult of the Renaissance and the overestimation of it as an epoch that divides the history of human civilisation into two. ${ }^{50}$ This comment is then followed by an assertion of the leading role of Northern European art in the fifteenth century, a view which is maintained in the introduction to the first volume of the Topography of Austrian Art (1907) where he suggests that the significance accorded to the art and architecture of Italy stems less from its actual historical importance than from the contingent fact that a greater number of the monuments of the Renaissance in Italy survived than elsewhere. ${ }^{51}$ Their physical ubiquity led them to be taken as a universal norm.

His lectures on the Italian Renaissance of 1918/19 reveal a similar scepticism towards the axiological role of Renaissance in art history; critiquing Burckhardt and his followers, Dvořák then justifies his topic by arguing that it is precisely its success that compels a reassessment. His comments merit quoting in full;

These lectures concern the history of Italian art from Giotto until the death of Michelangelo, in other words, those 250 years of Italian art history that have long counted as the high point of the entire development of art since antiquity - a high point that could only be followed by a deviation from this 
Published in: Art History, Vol. 26 No. 3 (2003) pp. 220-243

line of development, by decline. Today we are far removed from such a theory of ascent and decline, and one can quickly demonstrate that both the succeeding period - the Baroque era - and the art outside of Italy were no less creative or advanced, and that in terms of their significance for the present they were equal to Italian art between the fourteenth and the sixteenth centuries. Yet perhaps precisely because this dogmatic attachment to the Italian Renaissance belongs to the past, it is the object of a new kind of interest, not only as a particularly striking historical phenomenon, but also as the source of artistic opinions and innovations that continued to exercise influence on the entire succeeding period, even into the present. ${ }^{52}$

Dvořák's assertion regarding the Renaissance is meant as a deliberate provocation; the Renaissance cult of the end of the previous century had waned, but despite the efforts of Riegl and others, the Italian Renaissance remained of central importance to art historical scholarship. ${ }^{53}$ The founding of the Kunsthistorisches Institut in Florence in 1897 offers ample testimony to this, as does the centrality of the Renaissance for authors such as Heinrich Wölfflin, Carl Justi or August Schmarsow, working in the lengthy shadow of Burckhardt. Indeed, Schmarsow was instrumental in the establishment of the Kunsthistorisches Institut while for Wölfflin the Renaissance formed the point around the rest of the history of art was organised. ${ }^{54}$ Dvořák's comment is thus to be seen less as an observation on the present state of scholarship than as advocacy of his own position. Coupled with his reading of the posthumous reputation of El Greco, it highlights the extent to which he was engaged in contesting aesthetic norms and in articulating a critique of more general cultural values. And this is driven above all by a concern with the sense of correspondences between the past and the present. In the introduction to his lectures on the Italian Renaissance Dvořák acknowledges the contradiction between absorption in the minutiae of events belonging 500 years in the past, while being 'at a loss in the face of what might happen now and in the future,' yet at the same time he sees history as a source of encouragement to the present; ' $\ldots$ in such periods of political depression one can find solace in historical considerations, and perhaps even summon up courage and strength for the future ... ${ }^{55}$ This statement also reveals a further reason for his interest in the vicissitudes of the spiritual in art. In the introduction Dvořák's conducts what appears to be a purely methodological dispute over the limitations of the social history of art; citing the example of the Thirty 
Published in: Art History, Vol. 26 No. 3 (2003) pp. 220-243

Years' War he argues that the persistence of significant artistic production during a time of massive political violence and material deprivation indicates the autonomy of the cultural from the social and political sphere; 'in general, the intensity of intellectual and spiritual life is not dependent on material preconditions. ${ }^{56}$ Though ostensibly discussing the first half of the seventeenth century, he is, of course, talking of his own times, taking solace in the Thirty Years' War as a source of possible future hope in the final grim months of the Great War. In this Dvořák prefigured a much more famous reading of modernity through the lens of the Thirty Years' War: Walter Benjamin's The Origin of Geman Tragic Drama.$^{57}$ More usually mentioned in connection with Riegl, Benjamin's writing, with its emphasis on baroque modernity and on history as a source of redemption, displays an affinity with Dvořák seldom acknowledged.

As I have already observed, Dvořák states that the neglect of the spiritual in art was linked to the dominance of the classical aesthetic However, he broadens his perspective to suggest that such neglect is a function of the materialistic values that had emerged since. His essay on El Greco contains the most explicit use of history as an allegory of the present, and as an instrument for a critique of the present. Hence, El Greco's anti-naturalism is the sign of a broader shift originating in northern Europe which, 'like the current movement against capitalism, went against the worldliness of the Church and against the materialism which at that time seized the whole of religious life. ${ }^{58}$ Clearly, inasmuch as El Greco stands at the root of a cultural trajectory culminating in the idealism of Dvořák, so too his specific situation can be read as a figure of the present. El Greco's painting was the artistic response to a profound cultural crisis, 'an apparent chaos, in the same way that our age appears to us to be chaotic. ${ }^{59}$ In his analysis of the attempts to re-establish some kind of cultural meaning in the wake of the disruption of the Reformation, Dvořák could equally well be talking about his own times;

Following the collapse of a world-wide edifice, such as the world views of the late Middle Ages, the Renaissance and the Reformation, ruins necessarily emerge ... Thus we stand before a drama of enormous disturbance where, drawing on a colourful mixture of the old and the new, artists no less than philosophers, literary authors, scholars and politicians search in different directions for new crutches and goals. Artists, for example, do this by resorting to aesthetic virtuosity or new formal 
Published in: Art History, Vol. 26 No. 3 (2003) pp. 220-243

abstractions, which they imaginatively work up into academic doctrines and theories ... the range of subject matter increases in all directions, in relation to their need to gain attention and stress, in other words, the originality and individuality of their stance towards the world around them. ${ }^{60}$

While his own times are referred to here only indirectly, the essay culminates in a direct assertion of the link between the crisis being worked through in El Greco's painting and the contemporary situation;

Today this materialistic culture is faced with its termination. I am thinking here less of an external collapse, which would be a mere outward symptom, than of an internal one, which has been evident for a generation in all areas of intellectual life ... in that conspiracy of events which seems to be directing the secret law of human fate in the direction of a new spiritual and anti-materialistic age. ${ }^{61}$

For Dvořák the present was an era of crisis, a resolution of which he saw in a deepening of subjectivity, which established its cultural legitimacy by tracing a genealogy of the spiritual in art's history since late Antiquity. And he was also convinced that his own times would lead to a victory of the spiritual, a victory in which the Great War would play no small part. That the crisis of modernity found its culmination in the Great War is not mentioned in the essay on El Greco. However, in a pamphlet on Goya's Disasters of War published in 1916, Dvořák refers to the war in exactly the same terms as his wider diagnosis of modern culture. Indeed the war is viewed in terms of a deeper conflict of 'spiritual culture.' Having already welcomed the war as the occasion of a cultural clearing, as an opportunity for weeding out the dead and decaying, Dvořák declares at the conclusion that in the war 'liberal individualistic materialism was faced with a socio-ethical imperative, scientific positivism with a philosophical and historical idealism, and whoever examines this more closely could not doubt which of these two worlds was destined to victory from the very beginning. ${ }^{62}$ When Dvořák's collected essays were published posthumously in 1929 this essay, though included, was subjected to considerable revision; for obvious reasons, all reference to the war was omitted, and the essay concluded with a discussion of Goethe ${ }^{63}$ 
Published in: Art History, Vol. 26 No. 3 (2003) pp. 220-243

Dvořák's prediction of victory for the Habsburg Empire could be dismissed as crude patriotism were it not for the fact that it fits so neatly into his broader outlook, his valorisation of the spiritual, and his critique of the scientific outlook of Western modernity. It also draws on an established intellectual tradition - of which perhaps Friedrich Nietzsche is the most prominent example - that viewed political and military conflicts in terms of intellectual and 'geistig' crises. Indeed, Nietzsche read modernity as a crisis of values, of which the various contemporary social and political struggles were merely symptoms. It is worth noting in this context that as a young man in the mid-1890s Dvořák was profoundly affected by the work of Nietzsche, whose work was also of great importance for Dvořák's older contemporary Aby Warburg. ${ }^{64}$ Although Viennese Art History is usually deemed to constitute the antithesis of the iconological discourse pioneered by Warburg and his followers, Dvořák shared with Warburg a concern to locate art historical scholarship within ongoing debates about the crisis of contemporary culture. Warburg did not espouse the 'deep' subjectivity of Dvořák, but he held on to a similar utopia of a pre-industrial Enlightenment. As for Dvořák, so too for Warburg the principal cause of the crisis was the impact of the positivistic culture of the modern sciences and the machine age. This is expressed most forcefully in the ominous conclusion of his lecture on the serpent ritual of the Pueblo Indians;

... the culture of the machine age destroys what the natural sciences, born of myth, so arduously achieved; the space for devotion, which evolved in turn into the space required for reflection. The modern Prometheus and the modern Icarus, Franklin and the Wright brothers, who invented the dirigible airplane, are precisely those ominous destroyers of the sense of distance, who threaten to lead the planet back into chaos. ${ }^{65}$

\section{The Question of Modernity}

The comparison drawn by Dvořák between his own times and the cultural and ideological conflicts facing El Greco, Dürer, Tintoretto or Goya raises broader questions about the place of his writing, and of art historical writing more generally, within Viennese modernity. Wickhoff, Riegl, Dvořák and others maintained strong sympathies with the contemporary art of the time. Indeed, this interest distinguishes 
Published in: Art History, Vol. 26 No. 3 (2003) pp. 220-243

Viennese art historians of the late nineteenth and early twentieth centuries from their contemporaries in Germany or Switzerland, who remained ill at ease with contemporary art and for whom the Italian Renaissance remained the norm. Riegl's early professional involvement in the aesthetic practices of nonWestern cultures, together with his promotion of non-classical artistic forms, undoubtedly underlay his positive engagement with contemporary art, and the significance of his thought for modern art was soon recognised by others. As the critic Hermann Bahr stated in his tract on Expressionism;

[Riegl] was the first to recognise that before him all of Art History was subjective, in that it constantly approached art with a prejudiced eye, specifically, the prejudice of our taste which, schooled and dazzled by specific classical works, measures every artwork, from whatever era, against our memories of them ... he also admitted his conviction that in terms of development there is not only no such thing as decline, but also no point where development comes to a stop. ${ }^{66}$

Bahr's praise for Riegl - followed by an equally laudatory account of Franz Wickhoff - is only one example of such reciprocal relations between modernism and art historical discourse. One further example might be Worringer's extended celebration of Riegl in Abstraction and Empathy; in many respects this cornerstone of early modernist art theory formed an extension of Riegl's conceptual schemata to the analysis of 'primitive' and contemporary art. ${ }^{67}$ Moreover while Bahr celebrated the impact of Riegl on historiography, it is equally probable that Bahr's own prolific output of art and cultural criticism during the 1890s shaped the writings of Riegl and Wickhoff. Thus Bahr's description of decadence in his famous essay of 1894 , which focused on the importance of subjective mood ('Stimmung') as a defining characteristic of the 'neurotic romanticism' of contemporary art, is echoed only three years later in Riegl's essay on 'Mood as the Content of Modern Art,' an essay that replicates Bahr's own diagnoses of the relation between modernism and the modern sciences. ${ }^{68}$

Recognition of the interplay of art historical discourse and artistic practice in Vienna is important in countering an often dominant image of bourgeois art history as a conservative enterprise. However, it remains focused on questions of artistic taste and aesthetics; on Riegl's engagement with the 'aesthetics of 
Published in: Art History, Vol. 26 No. 3 (2003) pp. 220-243

disintegration,' as Margaret Iversen has put it. ${ }^{69} \mathrm{I}$ would like to suggest that the art historical writing of the fin-de-siècle and immediately after be considered in terms of its relation not only to contemporary aesthetic practices and theories, but also to currents in social theory and history that arose out of the attempt to make sense of late nineteenth-century European modernity. It is already clear that in the writing of Max Dvořák the history of art reflects much larger questions of cultural and social history - the spiritual crises of the age - and I would like to establish an alternative context for interpreting the significance of his thought. In so doing I shall use as a starting point Fritz Ringer's celebrated analysis of the rise (and fall) of the culture of the educated bourgeoisie (Bildungsbürgertum) in Germany, which Ringer terms, in line with its dominant role in forming the civil service within Germany, the 'mandarin' class. ${ }^{70}$ Although his account is largely focused on Germany, it is equally applicable, with some refinement, to the situation of the middle classes in Vienna.

According to Ringer, the ideology of the mandarin intellectuals can trace its origin to the outlook of the petits bourgeois of the late eighteenth century. In the absence of the mercantile and industrial opportunities present in Britain and France, this class found social advancement through education; the proliferation of absolutist states, with the consequent disproportionately large bureaucratic machinery, afforded widespread opportunities of entry into the civil service, as a compensation for the dearth of other possibilities for bourgeois advancement. Indeed, the lack of a mercantile class was appropriated as a sign of the intellectual and spiritual supremacy of German cultural life. The specificities of the mandarin ideology were also intimately linked to the political prominence given to universities in Germany, in contrast to the other major states of Europe. After the humiliation of defeat at the hands of Napoleon, the university of Berlin came to play a privileged role in the reassertion of Prussian national identity and cultural life; later, during the $19^{\text {th }}$ century, political rivalry between Prussia and Saxony was played out in the competing claims of Berlin and Leipzig universities to intellectual pre-eminence. ${ }^{71}$

The mandarin ideology placed the educated bourgeois, the Bildungsbürger, at the heart of national and political life. However, in Ringer's account the possibility of this being anything more than a utopian fantasy became increasingly improbable. Not only did the failure of the 1848 revolutions signal an end to 
Published in: Art History, Vol. 26 No. 3 (2003) pp. 220-243

hopes for a liberal bourgeois régime, but also the gradual industrialisation of Germany, with the creation of large working and entrepreneurial classes, meant that the mandarin outlook became increasingly disconnected from the realities of contemporary social and political life in the second half of the century. Within Germany such disenchantment grew further still in the aftermath of the Franco-Prussian war of 1870-71 and the creation of the Reich which, though raising hopes of a rebirth of German culture, only founded an authoritarian state structure from which the intellectuals in question felt ever more excluded.

For Ringer the mandarin ideology thus developed into an anti-modern stance that took issue with both the mercantile basis of capitalist society and the transformed social structures that were its consequence. The result was a self-conscious withdrawal from political and social life and the adoption of an aestheticised distance toward modernity. Social life came to be theorised in terms of subjective states - understanding, ideas, spirituality - rather than political praxis, and the very notion of the Bildungsbürger was predicated on the cultivation of an aestheticised intellectual inwardness. Dvořák's writings can be mapped onto Ringer's account with little difficulty. Where the mandarin ideology valorised subjective inwardness, Dvořák insisted on the primacy of the spiritual, and where mandarinism viewed modern society as a debased and degraded cultural landscape Dvoř́k inveighs against the materialist values of the age. Such parallels can be seen most clearly at the conclusion of his article on Dürer, in which the German artist is seen as introducing a new form of subjectivity;

There thus arises an artistic type diametrically opposed to that of contemporary Italy and the Netherlands, a new type of universal, ideal education ['Bildung'], a universalism not based on the empiricism of the natural sciences as was the case with Leonardo, but rather, as with Goethe 300 years later, one grounded in a ceaseless participation in everything that moves the spirit of man and provides nourishment for the imagination. ${ }^{72}$

Dürer was thus the prototype of the mandarin bourgeois, and it is significant that Dvorák chooses to distinguish between the positivistic connotations of empirical scientific observation on the one hand, and the participatory imaginative disposition of Goethe. The choice of Goethe is more than coincidental; in the 
Published in: Art History, Vol. 26 No. 3 (2003) pp. 220-243

years around the First World War he was foregrounded as the pre-eminent representative of the superiority of German intellectual culture.

Dvořák's own social origins in the mandarin class of a local cultural and administrative centre give added cause to view his work in terms of its class ideology. In this context it is notable that Riegl shared a similar class identity; indeed, the latter was often guilty of an exaggerated sense of class loyalty - demanding proper recognition of both his social status and his correct offical nomenclature. ${ }^{73}$ Ringer's account needs to be further amplified, however, by considering the specificities of the fading Habsburg régime. There were, of course, important parallels in the bourgeois experience of both Germany and Austria-Hungary; the failure of 1848 inflicted a similarly catastrophic defeat on the aspirations of bourgeois liberalism. In contrast, however, the liberals came to power in the constitutional régime in the 1860 s, although they retained a tenuous hold on power. Power was shared with the aristocracy and the imperial bureaucracy, and within a multi-ethnic empire the liberals, formed largely out of German nationals and German-speaking Jews, constituted a small minority. Austria-Hungary remained economically backward in comparison with Germany, and while this meant that the impact of industrialisation was initially less marked than in its neighbour, its delayed effects were felt all the more keenly. Between 1880 and 1910 the population of Vienna trebled, with a large part of the new inhabitants in the city stemming from the outer, non-Germanic, reaches of the Empire. ${ }^{74}$ The rise of new industrial classes also led to the emergence of mass political movements, ranging from pan-Slavism to socialism and German nationalism, all of which overwhelmed the liberal hegemony from the 1880 s onwards. The culmination of this process is often seen as being the election in 1895 of the anti-semitic Christian socialist Karl Lueger as mayor of Vienna, which Franz Josef II was eventually compelled to ratify in 1897.

The bourgeois experience in Austria-Hungary was thus marked by the traumatic memory of the recent loss of its tenuous hold on political life, coupled with the increasing antagonism between a feudal state apparatus and a socially and politically fragmented population. For Hugo von Hofmannsthal, for example, the era was best described as resting on multiplicity, indeterminacy and a universal slipperiness ('das 
Published in: Art History, Vol. 26 No. 3 (2003) pp. 220-243

Gleitende'), ${ }^{75}$ a situation of contradictions that Robert Musil, looking back later, described in all its frequent absurdity;

Officially it called itself the Austro-Hungarian Monarchy, but unofficially was referred to as Austria, a name, in other words, that had been solemnly and officially rejected, but which it retained ... Constitutionally it was liberal, but it was ruled by bureaucrats. It was ruled by bureaucrats but people lived freely. All citizens were equal before the law, but not all were citizens. There was a parliament that made such forceful use of its freedom that it was usually kept closed; however there was also an emergency decree thanks to which it was possible to continue without parliament, and whenever everyone was contented with absolutism, the crown ordained that parliamentary rule should be reinstated. Such events were frequent, and in addition there were the national conflicts ... these were so violent that several times a year the machinery of the state came to a standstill ... ${ }^{76}$

In his influential reading of fin-de-siècle Vienna Carl Schorske has interpreted the modernist culture of the Habsburg capital as a compensatory response to this condition, privileging an aestheticised subjective inwardness as an ideological mask that screened off the social contradictions of the age. As such it presented parallels with German mandarinism, except that the aesthetic retreat of, for example, the secessionist art of Klimt and others was accompanied by both the Freudian dismantling of the subject, and the philosophical positivism of Mach and, later, the Vienna Circle. The importance of Freud hardly needs restating, but it is notable that Mach's famous dictum that 'The ego is not to be retrieved' ('Das Ich ist nicht zu retten') offered a counter to the mandarin ideology of the self, in which the bourgeois subject, no longer seen as a point of refuge from the disappointments of mass society and its politics, had itself been reduced to a machine for processing stimuli. ${ }^{77}$ And it was a notion that was taken up in cultural criticism, most notably by Bahr. In an essay on 'The Irretrievable Ego' ('Das Unrettbare Ich') published in Dialogue on the Tragic (1904) Bahr declares;

Here I have found an expression for what has been torturing me all these past three years: "The I is not to be retrieved." It is just a name. It is just an illusion. It is a practical aid we employ in order to 
Published in: Art History, Vol. 26 No. 3 (2003) pp. 220-243

order our perceptions. There is nothing but connections between colours, tones, temperatures, pressures, spaces, times, and to these connections are bound moods, feelings and desires. Everything is constantly in a state of transformation. Whenever we speak of continuity this is only because some transformations occur slowly... ${ }^{78}$

In the same collection of essays Bahr also interprets Impressionism in the light of Mach; the reduction of the image to a manifold of visual sensations leads him to conclude that Mach's writing constitutes a 'philosophy of impressionism,' a view that ties in with a broader picture of contemporary art and culture, in which naturalism has come increasingly to be displaced by a new 'idealism' ('the content of the new idealism is nerves, nerves, nerves ...') exemplified in the work of Bizet, Maeterlinck, Degas and Puvis de Chavannes. ${ }^{79}$ Bahr's choice of examples appears now as eccentric, but his more general account is an important constituent of the complex configuration of often contradictory discourses within which the Vienna School of Art History has to be set. Indeed, his ideas anticipated the much more extended treatment of the topic by Richard Hamann, whose reading of impressionism as a general cultural phenomenon also drew on Georg Simmel's Philosophy of Money, interpreting impressionism as a direct reflection of the structural form of the monetary economy. ${ }^{80}$ More significantly, his Machian reading of Impressionism parallels Dvořák's early interpretation of Tintoretto which, in later shifting towards the idealist reading encapsulates the shifts and contradictions operative at the time.

Ringer's ideal-typical account has been criticised for its tendency to reduce intellectual life in Willhelmine Germany to a conservative anti-capitalist outlook; it has been argued that many social theorists such as Ernst Troeltsch, Georg Simmel or Max Weber approached the question of modernity with greater ambivalence than his account would suggest. Nevertheless, Werner Sombart's characterisation of politics as 'barren in spirit, mendacious in its ethics and aesthetically crude' was representative of a widespread disaffection with modern social and political life at the turn of the century ${ }^{81}$ What is often regarded as one of the founding texts of modern social theory, Ferdinand Tönnies' Community and Society of 1887, was organised around the distinction between the pre-modern community ('Gemeinschaft') in which all social relations were based on organic personalised ties, and the modern society ('Gesellschaft') which was 
Published in: Art History, Vol. 26 No. 3 (2003) pp. 220-243

structured around a series of abstracted anonymous relations. ${ }^{82}$ For Tönnies the latter was the result of an increasing differentiation of social functions leading to a generalised fragmentation of the social totality. It was a theory that found echoes amongst numerous other contemporaries writers. The effects of increasing social fragmentation were also recognised by Simmel, whose study 'On Social Differentiation,' published only three years after Tönnies' book, identified the analysis of differentiation as the prime task of social science, and clearly saw social atomisation as the principal marker of modernity; 'the dissolution of the soul of society into the sum total of the reciprocal effects of its members stems from the spiritual life of modernity in general: dissolving the constant, self-identical and substantial into function, force and movement, and recognising the historical process of becoming underlying all being. ${ }^{83}$ In Simmel's account modernity comes to be defined by the contradictions brought about by the dominance of the monetary economy: on the one hand a homogenisation of society through the depersonalisation of social relations and, on the other, an atomisation and fragmentation of society through a foregrounding of the individual. ${ }^{84}$ Simmel also identified the process of aestheticisation as a compensatory gesture in the face of the overwhelming experience of modernity, 'for in [art] alone there appears a complete victory of the spirit over the material substance of existence, or, rather more, we term "art" that activity in which the being of things, following their own laws and ultimately incomprehensible, has become fully pliant to the inner movements of the soul. ${ }^{, 85}$

It is perhaps clear from this account that the work of Dvořák, when viewed within the frame of early twentieth-century social theory, takes on new meanings. His history of art as the history of ideas becomes one more example of a wider set of discourses addressing the contradictions of modernity. The history of art becomes an allegory of the present, with an explicitness unparalleled in the work of his contemporaries. The question remains as to what conclusions might be drawn from such an analysis.

\section{Conclusion}

Few now regard Dvořák's work on Tintoretto, El Greco, Michelangelo or Gothic art as significant for contemporary scholarship. His texts can be read in in an alternative light, however, when considered as 
Published in: Art History, Vol. 26 No. 3 (2003) pp. 220-243

examples of modernist writing, exploring the possibilities of a non-classical history of art in a manner that parallels other contemporary forms of social and cultural commentary. From this perspective, while art history emerged from specific configuration of institutional sites and discourses, it is limiting to view Dvořák’s work entirely within such an institutional frame. Rather, it has more in common with other contemporaneous discursive genres; his art history is an articulation of the experience of Viennese modernity akin to the fiction of Musil and Schnitzler, the poetry and drama of Hofmannsthal, the criticism of Bahr, or the psychological theories of Mach and Freud.

The neglect of Dvorák undoubtedly stems from the fact that in methodological terms his 'art history as the history of ideas' has come to be seen as theoretically underdetermined and simplistic. In terms of establishing the broader cultural, discursive and intellectual frame of the discipline, however, Dvořák offers important clues to the development of art history as a heteronomous practice. And to his name could be added those of other Viennese colleagues whose work, often passed over in embarrassed silence, reveals the complex ideological commitments of the discipline and its relations to other discourses. These might include, for example, Hans Sedlmayr or Strzygowski. While the latter's ethno-history of art anticipated Nazi ideologies of ethnicity, he was also fiercely critical of the occidental focus of traditional art history, pioneering the study of Slavic, Coptic and Armenian art, and putting forward a model of Western culture as an open heteronomous configuration of practices. Thus, critical reflection on origins past of art history has to pass beyond the canonical 'founding fathers' of the discipline, to consider those marginal, overlooked discourses that equally represent the often complex and contradictory conceptual, socio-historical and ideological frames operative throughout its history. 
Published in: Art History, Vol. 26 No. 3 (2003) pp. 220-243

${ }^{1}$ See, for example, Robert Hedicke, Methodenlehre der Kunstgeschichte, Strasbourg, 1924; Dagobert Frey, Gotik und Renaissance als Grundlagen der modernen Weltanschauung, Augsburg, 1929; Otto Benesch, The Art of the Renaissance in Northern Europe: Its Relation to the Contemporary Spiritual and Intellectual Movements, Cambridge, Mass., 1945.

${ }^{2}$ A most striking instance of this phenomenon is the recent Vienna School Reader, which omits him entirely, providing merely a seven line synopsis of his work in the Introduction; see Christopher Wood, ed., The Vienna School Reader, New York, 2000. The more notable recent literature on Dvořák includes: Norbert Schmitz, Kunst und Wissenschaft im Zeichen der Moderne, Alfter, 1993; Mitchell Schwarzer, ‘Cosmopolitan Difference in Max Dvořák’s Art Historiography', in Art Bulletin, vol. LXXIV, no. 4, 1992, pp. 669-78; Irma Emmrich, 'Max Dvořák und die Wiener Schule der Kunstgeschichte', in Dvořák, Studien zur Kunstgeschichte, ed. Irma Emmrich, Leipzig, 1989, pp. 311-59; Momír Vaněk, 'L’Ecole Française et l'Ecole Viennoise d'Histoire de l'Art: Max Dvořák et Henri Focillon. Antagonisme ou Complémentarité?' in L. Ettlinger, ed., Wien und die Entwicklung der Kunsthistorischen Methode, Vienna, 1984, pp. 105-15; Hans Busse, Kunst und Wissenschaft. Untersuchungen zur Ästhetik und Methodik der Kunstgeschichtswissenschaft bei Riegl, Wölfflin und Dvořák, Mittenwald, 1981, pp. 85-108 Sandor Radnóti, 'Die Historisierung des Kunstbegriffs: Max Dvořák,' in Acta Historiae Artium, vol. 26, 1980, pp. $125-42$.

${ }^{3}$ See Wood, op. cit., p. 30.

${ }^{4}$ Mikhail Bakhtin and P. N. Medvedev, 'The Formal Method in European Art Scholarship', in The Formal Method in Literary Scholarship, trans. A. Wehrle, Baltimore, 1978, pp. 41-53; Elizabeth Mansfield, 'Art History and Modernism,' in Mansfield, ed., Art History and its Institutions, London, 2002, p. 17.

${ }^{5}$ On the Czech background to Dvořák see Hugo Rokyta, 'Max Dvořák und seine Schule in den Böhmischen Ländern', in Österreichische Zeitschrift für Kunst- und Denkmalpflege, vol. XXVIII, no. 3, 1974, pp. 81-89. 
Published in: Art History, Vol. 26 No. 3 (2003) pp. 220-243

${ }^{6}$ Max Dvořák, 'Die Illuminatoren des Johann von Neumarkt', in Jahrbuch der Kunsthistorischen Sammlungen des Allerhöchsten Kaiserhauses (1901, pp. 35-127, reprinted in Dvořák, Gesammelte Aufsätze zur Kunstgeschichte (Munich, 1929, pp. 74-207.

${ }^{7}$ Max Dvořák, Kunstgeschichte als Geistesgeschichte, Munich, 1923. The essays contained in this volume were translated as two separate English-language publications: Art History as the History of Ideas, trans. J. Hardy, London, 1984, and Idealism and Naturalism in Gothic Art, trans. R. Klawiter, Notre Dame, 1967. ${ }^{8}$ Max Dvořák, Das Rätsel der Kunst der Brüder van Eyck, Munich, 1925; Geschichte der italienischen Kunst im Zeitalter der Renaissance. Akademische Vorlesungen, Munich, 1927-1929; Gesammelte Aufsätze zur Kunstgeschichte (see n. 7). The study of van Eyck has been republished recently as Dvořák, Das Rätsel der Brüder van Eyck, Vienna, 1999. The essays of Kunstgeschichte als Geistesgeschichte have been republished, alongside some of the lectures on the Italian Renaissance in Dvořák, Studien zur Kunstgeschichte (see n. 2).

${ }^{9}$ The volume of Gesammelte Schriften includes a bibliography of works (pp. 371-81) published in Dvořák's lifetime.

${ }^{10}$ For an outline of the feud between Riegl and Strzygowski see Jaś Elsner, 'The Birth of Late Antiquity: Riegl and Strzygowski in 1901', in Art History, vol. 25, no. 3, 2002, pp. 358-79.

${ }^{11}$ Franz Wickhoff and Wilhelm Hartel, Die Wiener Genesis, Vienna, 1895.

${ }^{12}$ Franz Wickhoff, ‘Über die Einteilung der Kunstgeschichte in Hauptperioden’, in Wickhoff, Abhandlungen, Vorträge und Aufsätze, ed. M. Dvorák, Berlin, 1913, vol. II, pp. 446-54.

${ }^{13}$ In a well-known passage of Historik Droysen states: 'The hundreds of pictures in a gallery ... Art History places them in a context they do not possess in themselves, and for which they were not painted, and from which there arises a sequence, a continuity, under the influence of which the painters of these pictures stood without being aware.' Johann Gustav Droysen, Historik. Enzyklopädie und Methodologie der Geschichte, Munich, [1858] 1958, p. 35.

${ }^{14}$ Alois Riegl, 'Eine neue Kunstgeschichte’, in Riegl, Gesammelte Aufsätze, ed. A. Rosenauer, Vienna, [1928] 1996, p. 45. 
Published in: Art History, Vol. 26 No. 3 (2003) pp. 220-243

${ }^{15}$ Alois Riegl, Altorientalische Teppiche, Mittenwald, [1892] 1979, and Riegl, Problems of Style, trans. E. Kain, Princeton, [1893] 1992.

${ }^{16}$ Margaret Olin, 'Alois Riegl: the Late Roman Empire in the Late Habsburg Empire', in Austrian Studies, Vol. 5, 1994, pp. 107-20.

${ }^{17}$ Alois Riegl, Die Entstehung der Barockkunst in Rom, Vienna, 1908, p. 2 ff.

${ }^{18}$ See Mitchell Schwarzer, 'Cosmopolitan Indifference in Max Dvorák’s Art Historiography,' in Art

Bulletin, vol. LXXIV, no. 4, 1992, pp. 669-78.

${ }^{19}$ Julius Langbehn, Rembrandt als Erzieher, Berlin, 1888.

${ }^{20}$ Max Dvorák, 'Idealismus und Naturalismus in der gotischen Skulptur und Malerei’, in Dvorák, Studien zur Kunstgeschichte, p. 162.

${ }^{21}$ Dvořák, Gesammelte Aufsätze, p. 207.

${ }^{22}$ Dvorák, see n. 7.

${ }^{23}$ Karel van Mander, Lives of the Illustrious Netherlandish and German Painters, 6 Volumes, Doornspijk, 1994-99.

${ }^{24}$ Dvořák, Das Rätsel der Brüder van Eyck, Vienna, 1999, p. 145.

${ }^{25}$ Ibid., p. 215.

${ }^{26}$ Max Dvorák, ‘Über die dringendsten methodischen Erfordernisse der Erziehung zur kunstgeschichtlichen Forschung', in Die Geisteswissenschaften No. 34, 1913, p. 934.

${ }^{27}$ Ibid., p. 935.

${ }^{28}$ Dvořák, 'Barockkunst' [1905/1906] cited in Hans Aurenhammer, 'Max Dvorák, Tintoretto und die Moderne: Kunstgeschichte “vom Standpunkt unserer Kunstentwicklung” betrachtet', in Wiener Jahrbuch für Kunstgeschichte, vol. IL, 1992, p. 15.

${ }^{29}$ Cited in ibid., p. 16.

${ }^{30}$ See, for example, Konrad Fiedler, Über die Beurteilung von Werken der bildenden Kunst, Leipzig, 1876, or Adolf Hildebrand, 'The Problem of Form in the Fine Arts' [1893], in Harry Mallgrave and Eleftherios Ikonomou, eds., Empathy, Form and Space. Problems in German Aesthetics 1873-1893, Los Angeles, 1994, pp. 227-80. 
Published in: Art History, Vol. 26 No. 3 (2003) pp. 220-243

${ }^{31}$ On the Baroque in early twentieth-century art history see my 'Subjectivity and Modernism: Riegl and the Rediscovery of the Baroque', in Richard Woodfield, ed., Framing Formalism. Riegl's Work, Amsterdam, 2001, pp. 265-90.

${ }^{32}$ See Franz Wickhoff, Römische Kunst, Berlin, [1895] 1912, p. 137. See too the Impressionism exhibition catalogue, Entwicklung des Impressionismus in Malerei und Plastik, Vienna, 1903.

${ }^{33}$ Robert Jensen, Marketing Modernism in Fin-de-Siècle Europe, Princeton, 1994.

${ }^{34}$ Jakob Burckhardt, Der Cicerone. Eine Anleitung zum Genuß der Kunstwerke Italiens, Leipzig, [1855] 1925, p. 932.

${ }^{35}$ Cited in Aurenhammer, op. cit., p. 24.

${ }^{36}$ Dvořák, ‘Tintoretto,' in , Studien zu Kunstgeschichte, p. 149.

${ }^{37}$ Ibid., pp. 141-42.

${ }^{38}$ Dvoř́k, Studien zu Kunstgeschichte, p. 75.

${ }^{39}$ Ibid., pp. 283-4.

${ }^{40}$ Ibid., p. 159.

${ }^{41}$ Dvořák, 'Dürers Apokalypse', in ibid., pp. 5-15. Dvořák’s work also echoes the contrast drawn by Riegl between Italian art, focused primarily on the representation of external human agency, and Northern art, focused on the depiction of inner subjective states. See Riegl, The Group Portraiture of Holland, trans. E. Kain, Los Angeles, [1902] 1999.

${ }^{42}$ Dvořák, Studien zu Kunstgeschichte, p. 15.

${ }^{43}$ Ibid., p. 82.

44 ‘Über Greco und den Manierismus' and 'Katacombenmalerei. Die Anfänge der christlichen Kunst', in Dvořák, Studien zu Kunstgeschichte, pp. 59-75 and 269-310.

${ }^{45}$ See Norbert Schmitz, 'Max Dvořák - Das Spirituelle in der Kunstgeschichte', in Schmitz, op. cit., pp. 255-324

46 'Vorwort', in Oskar Kokoschka. Variationen über ein Thema, Vienna, 1921, reprinted in H. Wingler and F. Weltz, eds., Oskar Kokoschka. Das Druckgraphische Werk, Salzburg, 1975, pp. 40-42. 
Published in: Art History, Vol. 26 No. 3 (2003) pp. 220-243

${ }^{47}$ Dvořák, 'Lectures on Idealism and Naturalism in Gothic Painting and Sculpture,' Winter Semester 1915/16, p. 2. The typescript is kept in the archive of the Institute of Art History of the University of Vienna.

${ }^{48}$ Ibid., p. 1.

${ }^{49}$ Dvořák, Studien zu Kunstgeschichte, p. 75.

${ }^{50}$ Dvořák, Das Rätsel der Brüder van Eyck, p. 145.

${ }^{51}$ Dvořák, ‘Einleitung zum Ersten Band der Österreichischen Kunsttopographie’, [1907], reprinted in Österreichische Zeitschrift für Kunst- und Denkmalpflege, vol. XXVIII, no. 3, 1974, p. 107.

${ }^{52}$ Dvořák, Geschichte der Italienischen Kunst, Munich, 1927, vol. I, p. 3.

${ }^{53}$ On the Renaissance cult in Germany see Helmut Koopmann, 'Renaissancekult in der Deutschen Literatur um 1900', in Max Seidel, ed., Storia dell'Arte e Politica Culturale Intorno al 1900, Venice, 1999, pp. 1324.

${ }^{54}$ On the founding of the Kunsthistorisches Institut see Hans Hubert, 'August Schmarsow, Hermann Grimm und die Gründung des Kunsthistorischen Instituts in Florenz', in M. Seidel, op. cit., pp. 339-58.

${ }^{55}$ Dvořák, Geschichte der Italienischen Kunst, vol. I, p. 4.

${ }^{56}$ Ibid., p. 4.

${ }^{57}$ Walter Benjamin, The Origin of Geman Tragic Drama, trans. J. Osborne, London, 1977.

${ }^{58}$ Dvořák, Studien zu Kunstgeschichte, p. 68

${ }^{59}$ Ibid., p. 69.

${ }^{60}$ Ibid., pp. 69-70.

${ }^{61}$ Ibid., p. 75

${ }^{62}$ Dvořák, 'Eine Illustrierte Kriegschronik vor hundert Jahren, oder der Krieg und die Kunst', in KriegsAlmanach, 1916, p. 12.

63 'Eine illustrierte Kriegschronik,' in Dvořák, Gesammelte Aufsätze zur Kunstgeschichte, pp. 42-49.

${ }^{64}$ See the report by Karl Swoboda in 'Vortrag zum 30. Todestag von Max Dvoř́a'k', in Österreichische Zeitschrift für Kunst- und Denkmalpflege, vol. XXVIII, no. 3, 1974, p. 76. 
Published in: Art History, Vol. 26 No. 3 (2003) pp. 220-243

${ }^{65}$ Aby Warburg, Images from the Region of the Pueblo Indians of North America, trans. M. Steinberg, Ithaca, 1995, p. 54.

${ }^{66}$ Hermann Bahr, Der Expressionismus, Munich, 1919, p. 72.

${ }^{67}$ Wilhelm Worringer, Abstraktion und Einfühlung. Ein Beitrag zur Stilpsychologie, [1908], Munich, 1919, p. $10 \mathrm{ff}$.

${ }^{68}$ Bahr, 'Décadence', in Bahr, Studien zur Kritik der Moderne, Frankfurt am Main, 1894, pp. 26-32. Riegl, 'Die Stimmung als Inhalt der modernen Kunst' in Gesammelte Aufsätze, pp. 27-37. Perhaps the best known example of such advocacy of contemporary art was Wickhoff's intervention in the controversy surrounding Klimt's Philosophy mural commissioned for the ceiling for the Great Hall of the University. For an outline of the affair see Michael Ann Holly, 'Spirits and Ghosts in the Historiography of Art', in Mark Cheetham, Keith Moxey and Michael Ann Holly, eds., The Subjects of Art History, Cambridge, 1998, pp. 52-73.

${ }^{69}$ M. Iversen, Alois Riegl. Art History and Theory, p. $32 \mathrm{ff}$.

${ }^{70}$ Fritz Ringer, The Decline of the German Mandarins. The German Academic Community 1890-1933, Cambridge, Mass., 1969.

${ }^{71}$ On the rise of Leipzig university as an important intellectual centre see Woodruff Smith, 'Intellectual Politics and Cultural Science in the Wilhelmian Era', in Politics and Sciences of Culture in Germany, Cambridge, 1991, pp. 193-218.

${ }^{72}$ Dvořák, Studien zu Kunstgeschichte, p. 15.

${ }^{73}$ See Olin, op. cit., p. 109. Olin also suggests that the clash between Riegl and Strzygowski was driven by class antagonism, the latter coming from the mercantile classes often looked upon with considerable disdain.

${ }^{74}$ See Dagmar Lorenz, Wiener Moderne, Stuttgart, 1995, p. 14 ff.

${ }^{75}$ Cited in Schorske, op. cit., p. 19.

${ }^{76}$ Robert Musil, cited in Lorenz, op. cit., pp. 8-9.

${ }^{77}$ Ernst Mach, The Analysis of Sensations, trans. C. Williams, New York, [1886] 1959, p. 24, translation slightly altered.

${ }^{78}$ Bahr, 'Das Unrettbare Ich,' in Bahr, Dialog vom Tragischen, Berlin, 1904, pp. 97-8. 
Published in: Art History, Vol. 26 No. 3 (2003) pp. 220-243

${ }^{79}$ Bahr, Die Überwindung des Naturalismus, Dresden, 1891, p. 157-8.

${ }^{80}$ Richard Hamann, Der Impressionismus in Leben und Kunst, Cologne, 1907. Georg Simmel, Philosophie des Geldes, [1900], in Simmel, Gesamtausgabe, vol. 6, Frankfurt am Main, 1989.

${ }^{81}$ Werner Sombart, 'Die Politik als Beruf' in Morgen $26^{\text {th }}$ July 1907, p. 197. On Sombart and politics see F. Lenger, 'Die Abkehr von der Politik: Werner Sombart und der "Morgen" ', in G. Hübinger and W. Mommsen, eds., Intellektuelle im Deutschen Kaiserreich, Frankfurt am Main, 1993, pp. 62-77.

${ }^{82}$ Ferdinand Tönnies, Gemeinschaft und Gesellschaft, Leipzig, 1887.

${ }^{83}$ Georg Simmel, ‘Über Sociale Differenzierung’ [1890] in Simmel, Gesamtausgabe, vol. 2, p. 130.

${ }^{84}$ See Simmel, 'Das Geld in der modernen Cultur' [1896] in Simmel, Gesamtausgabe, vol. 5, pp. 178-96.

${ }^{85}$ Simmel, 'Rodins Plastik und die Geistesrichtung der Gegenwart,' in Simmel, Gesamtausgabe, vol. 7, p. 97. 